\title{
ミナミキイロアザミウマにおける殺虫剤感受性の季節変動
}

西野 敏勝 (長崎県総合農林試験埸)

\section{Seasonal fluctuation of susceptibility to insecticides in Thrips palmi KARNY.}

Toshikatsu NiSHINo (Nagasaki Agricultural and Forestry Experiment Station, Isahaya, Nagasaki 854)

長崎県にミナミキイロアザミウマが初発生した1981年 の春と秋で本種の薬剤感受性が大きく変化し，秋には本 種の DMTP 水和郕に対する感受性が極端に低下した。 僅かな期間に薬剤感受性が著しく低下するとすれば，早 急に代替薬剤の検討とその防止対策を確立する必要があ った。

そこで，代表的な防除薬用である DMTP 水和凨と BPMC 乳剂を用いて，1984年から楽剤淘汰試験を開始 し，薬郕感受性の推移を 2 年間にわたって調查した結果， 薬剛抵抗性の発達と感受性の季節変動に関して若干の知 見を得たので報告する。報告に先立ちコリンエステラー ゼ活性の測定を快くご指導いただいた九州農業試験場虫 害第 2 研究室長風野光氏心厚くお礼申し上げる。

\section{材料及び方 法}

\section{1，薬刘による淘汰試験}

調査区は DMTP 水和唷淘汰区, BPMC 乳剂淘汰区, 両薬敵の無処理区の3区を設けた。各区は大型ガうス空 を 3 等分して，幅 $5 \mathrm{~m}$ 長さ $8 \mathrm{~m}$ の大きさとし，各区の外 側及び区間は網目 $0.7 \mathrm{~mm}$ の網で仕切り，無処理区の中央 仕切りには網の上からビニールを張ってミナミキイロア ザミゥマの侵入を防止した。いずれも68本のナスを1983 年11月に定植して試験を開始したが，以後は32本を下ま わらないように実生苗を移植して各区の個体群を維持し た。

薬侴淘汰はミナミキイロアザミウマが十分増殖した時 に行い，第 2 表に示すようにDMTP 水和剂は 2 年間で 23回，BPMC 乳剂は25回淘汰を行った。無処理区では， アブラムシ，ハダニ，オンシッコナジラミ等が発生して 本虫の增殖を抑制するので，ミナミキイロアザミウマに 最初から效果がほとんどなかった薬郕を選定して，第 1 表に示すような薬剤を散布した。これら薬郕は薬剤淘汰 区に詨しても同時期に散布した。

\section{2. 慗凮感受性検定方法}

小型ペトリ皿に0.6\%の寒天ゲルを浅く流し込み，イ
ンゲンの新葉を幅 $2.5 \mathrm{~cm}$ 長さ $3 \mathrm{~cm}$ の大きさに切ってその 上に置き，葉縁を浅く寒天に押しこんで乾燥を防止した。 この1葉片に15－20頭の㸡成虫を接種し，パラフィルム で蓋をして1.5日間産卵させた。その後，成虫を除去し， ガラスの蓋をして 5 - 6 日飼育後の 2 龄幼虫の初期に, 所定濃度の薬剤を薬剂散布塔で 1 ペトリ血当り $12 \mathrm{~m} \ell$ 散布 した。散布後薬郕の乾燥を待ってガラス蓋をかぶせ， 24 時間後の死虫率を調查した。2 年間の各時期とも成虫の 産卵，飼育及び薬剂処理後の放置は，す心゙て $25^{\circ} \mathrm{C} の$ 恒温 器（士1 $\mathrm{C}$ 程度）を用いて行った。検定は約 1 か月每に 行々, 無処理区は DMTP 水和唷と BPMC 乳剂, 各淘 汰区は汻汰薬剤を対象に5濃度レベルで死虫率を調查し， LC50 值を算出した。

\section{3. コリンエステラーゼ活性の測定}

ELLMAN らの方法により Shimadzu UV-240自記分光 光度計を使用して测定した。具体的な方法は前報で風 野・西野（1986）が報告したと打りである。即ち、ミナ

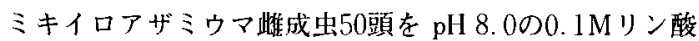
緩衝液で磨砕, $1.000 \mathrm{rpm} 5$ 分間遠沈した上清 $3 \mathrm{m \ell}$ を所

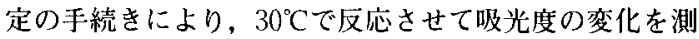
定した。殺虫剛は原体の所定量をアセトンに溶かし，対 照区の測定では殺虫剤を含まないアセトンを用いた。

\section{結果及び考察}

\section{1. 無処理区における楽風感受性の季節変動}

DMTP と BPMCを 2 年間まったく散布しなかった ガラス室において，両薬郕に対する感受性の変動を調查 した結果は第 1 図のとおりりである。 $\mathrm{LC}_{50}$ 值の推移をみ ると，雨楽郕ともほぼ似たような季節変動を示した。即 ち，2-4 月頃の感受性が高く，以降徐々に感受性は低 下して 8〜10月頃が薬郕に対して最も強い時期であった。 その程度の善は， 2〜4月の LC50值を基準にして 8一

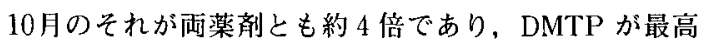
$400 \mathrm{ppm}$ に対して BPMC は800 ppm であった。10月以 降冬を越して再び2 4 月になると，前年と同レべルの 
第 1 表 DMTP 及び BPMC 以外の薬骩散布実縜

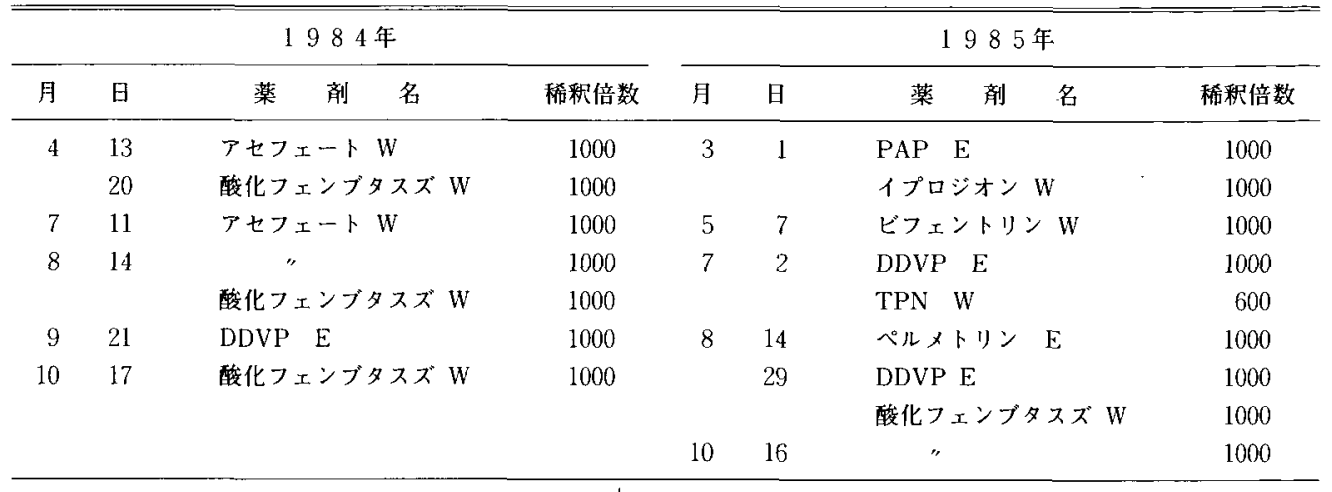

注） $W$ : 水和戍， $E$ : 乳剂

第2 表薬敵潮汰区に打ける薬郕散布回数

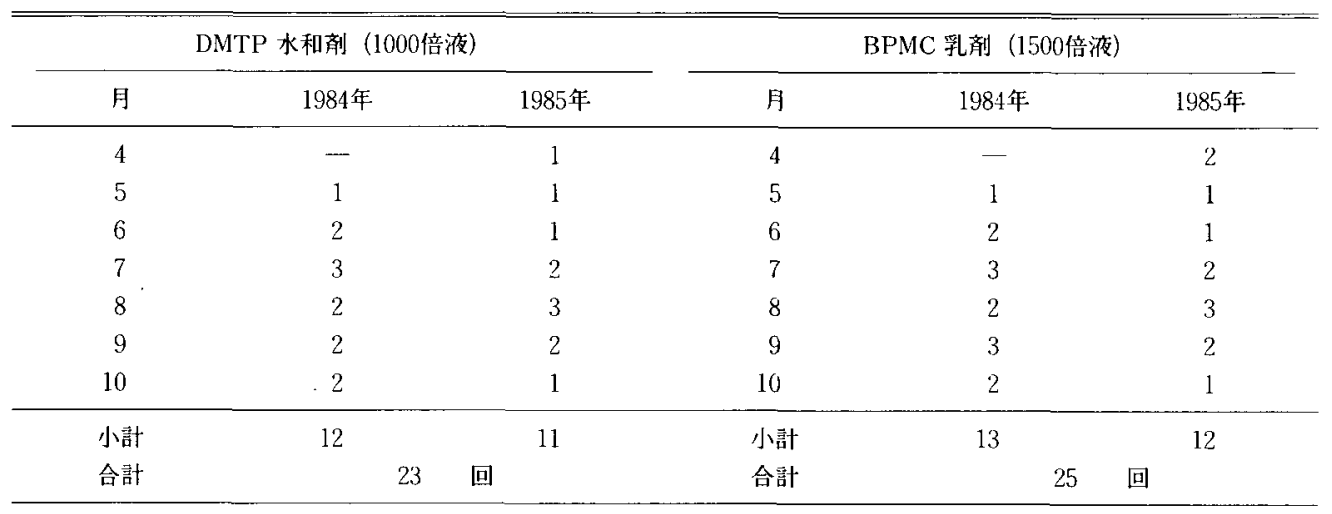

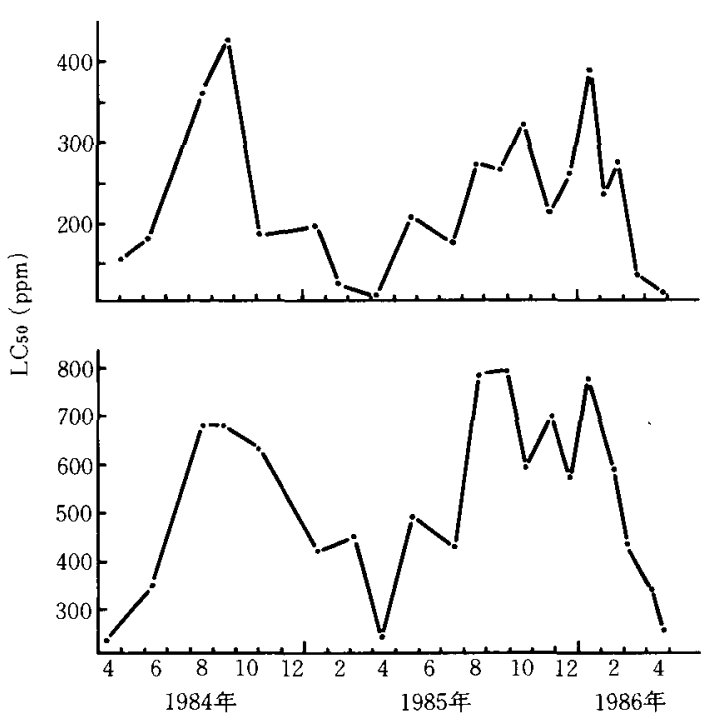

第 1 図 無処理区における薬剂感受性の季節変動 上段：DMTPに对する感受性 下段：BPMCに对する感受性
高い感受性に復元している。この傾向は 2 年間にわたっ て而薬郕とも認められた。

薬片感受性の野外における季節㚆動には大きくわけて 3 つの内容が包含されていると思わ和る。第 1 は， 1 年 間の楽剛滛汰により感受性であったものが抵抗性に変化 する場合で，永田·守谷（1974）はトビイロウンカの初 期飛来虫に比べて第 4-5回成虫は感受性が顕著に低下 し，14〜19倍の差を認めた例。第 2 は，薬剤抵抗性とは 関係なく，薬䇕の性質によって夏季に効果が高くなり冬 季に低下するもの, またその逆の場合がある。第 3 は, 抵抗性の発達や薬棛の温度反忘とは無関俰に，おそらく 虫自体の生理形態的な面と思われるが, 感受性の程度が 季節的に変化する場合である。本研究における無処理区 では，検定菜剤の淘汰は甥いていないし，検定の際は各 時期とも $25^{\circ} \mathrm{C}$ 一定温度条件下に置かれている。従って, 本研究で得られた菜戍感受性の季節変動は上記の第 $3 の$ 場合に当り, 現地で薬梸抵抗性の発達程度を調べ，その 結果を判断する場合に大きな問題となる。 
薬剤感受性が季節によって変化するという報告は, 松 谷 (1967)，DITTRICH（1963）のハダニに打ける報告等 いくつか発表されている。松谷はニセナミハダニにおい て，温宝内のインゲンで飼有したハダ二を用い，クロル ベンジレートに対する感受性の季節変動を検討した。そ の結果, 毎年（4 年間）12〜 4 月までは感受性が高く, その後徐々に低下して 8 月には感受性が最低となり，以 後再び上昇して12月には前年のレベルにもどったと報告 している(フェンカプトンではいくぶん傾向がことな る)。この結果はミナミキイロアザミウマの傾向とよく 一致する。また，松谷（1967）は更に恒温器で飼育した ニセナミハダニで同様の試験を行ったが，この場合は感 受性の季節変動が小さいとしている。

松谷（1967）はこのような薬剤感受性の季節変動を誘 起する原因として、温度、湿度、光線等が直接虫に作用し て虫の生理形態を変化させる場合, 奇主植物に作用して 栄養条件を変化させ閒接的に出に影響する場合，両方が 一緒に影響を与える場合が考えられるとしている。従っ て，ミナミキイロアザミウマにおける場合も薬剤感受性 季節変動の原因解明には，本種の生理，形態等の変化の 究明とともに寄主の栄養状態の影響についても究明する 必要がある。

\section{DMTP 水和剤淘汰区における菜剤感受性の推移}
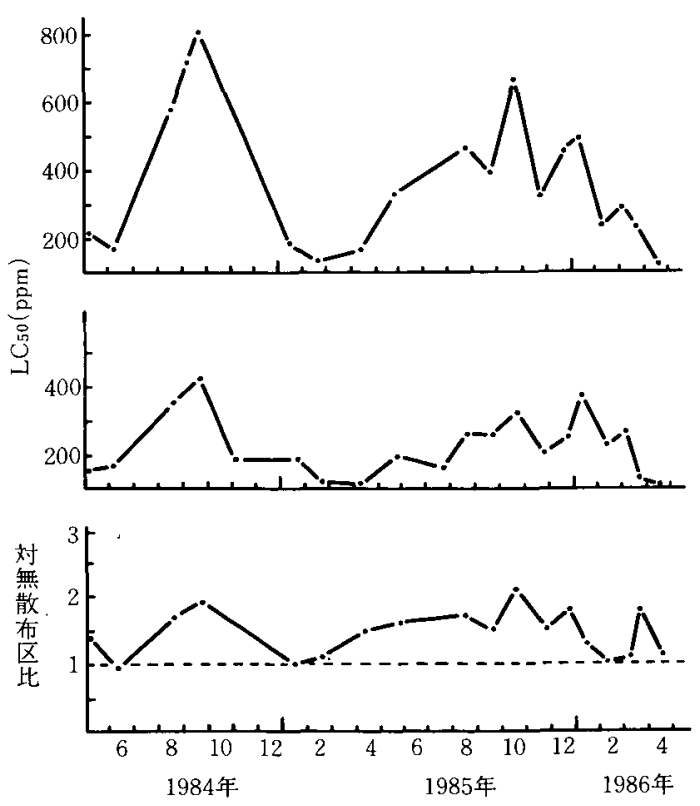

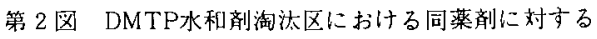
感受性推移

上段：DMTP水和剂海汰区における感受性推 移

中段：無処理区における感受性推移

下段：薬戍淘汰区LC50值の对無処理区比の推
DMTP 水和珮の散布回数は第 2 表に示すとおり 2 年 間で合計23回で, 同薬剤の検定結果は第 2 図のとおりで ある。薬剂感受性の推移は 2 年間とも無処理区と全く同 様の傾向を示し， LC50 值は $2 \sim 4$ 月が最小で $8 \sim 10$ 月 に大きい値を示した。見かけの感受性低下は 7ー8倍と かなり大きいが，無处理区の感受性も低下しており，そ れとの比を見れば両年とも約 2 倍の感受性低下であった。 その推移は第 2 図の下段に示すとおり，無处理区におけ る推移と同様である。即ち，4 月以降 DMTP を11 12 回散布した場合，10月頃には 4 月に比べて約 2 倍の感受 性低下が認められるが，その後冬を越して翌年の2～4 用頃に至ると，前年の同時期の感受性レベルに復元して いる。この傾向は 2 年目も確認され，2年間23回の淘汰 にもかかわらず感受性が復元することから, 井上 （1986）がミカン八ダ二のケルセン抵抗性の遺伝的特性 で明らかにしたように，不完全劣性遺伝子が関与してい るのか今後の検討が必要である。

\section{BPMC 乳剤淘汰区における薬剤感受性の推移}

BPMC 乳剤の散布回数を第 2 表, 感受性の推移を第 3 図に示した。BPMCではDMTPに比較すると，薬 剂淘汰回数の少ない時期から感受性が低下している。無 处理区における BPMCの效果が全体に低下しており， 2 年目の $\mathrm{LC}_{50}$ 值が大きい傾向にある。越年後の感受性
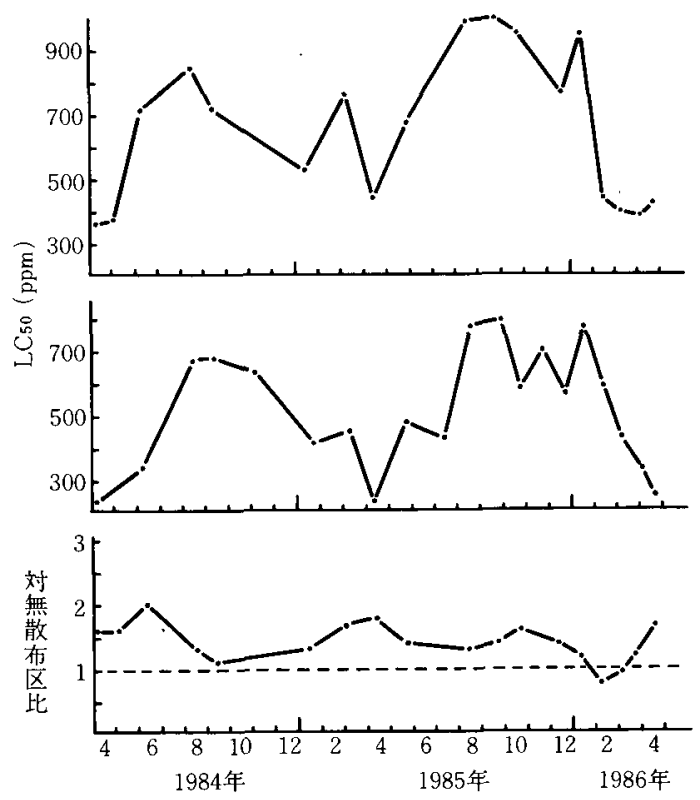

第 3 図 BPMC乳剂㴾汰区における同薬剤に対する感 受性推移

上段：BPMC乳剂汻汰区における感受性推移 中段：無処理区における感受性推移

下段：薬剂淘汰区LC 50 值の対無処理区比の推 移 
第 3 表 ミナミキイロアザミウマの ChE に対する BPMC, DMTP-オクンンの阻害度

\begin{tabular}{|c|c|c|c|}
\hline \multirow[b]{2}{*}{ 区 } & \multirow[b]{2}{*}{ 阻害 } & \multicolumn{2}{|c|}{ I50 (M) } \\
\hline & & $\begin{array}{c}\text { 1985年 } \\
\text { 10月23日 }\end{array}$ & $\begin{array}{c}\text { 1986年 } \\
3 \text { 月20日 }\end{array}$ \\
\hline DMTP 淘汰区 & \multirow{2}{*}{ DMTP-OXON } & $114 \times 10^{-i}$ & $14 \times 10^{-7}$ \\
\hline DMTP 無処理区 & & $52 \times 10^{-7}$ & $10 \times 10^{-7}$ \\
\hline BPMC 淘汰区 & \multirow{2}{*}{$\mathrm{BPMC}$} & $249 \times 10^{-8}$ & $27 \times 10^{-8}$ \\
\hline BPMC 無処理区 & & $44 \times 10^{-8}$ & $11 \times 10^{-8}$ \\
\hline
\end{tabular}

復元は DMTP のように顕著ではなかった。

いずれにしても，DMTP，BPMC とも 2 年間23〜25 回の薬冎淘汰では感受性の低下は磪認できなかった。

\section{4. 各処理区における ChE の感受性}

無処理区，DMTP及び BPMC 御汰区における， DMTP-オクンン及び BPMC のミナミキイロアザミウ マの ChEに対する50\%阻害度（I50）は第 3 表のとおり である。DMTP 淘汰区では感受性低下の著しい10月に, I50の值が無処理区に比べて 2 倍, 感受性が復元する 3 月に比較して約10倍の値を示し，無処理区における10月 のI50は3月に比較して5倍の值が得られた。これは。 先に述べた薬郕感受性の LC50 值の推移とよく一致してい る。

有機りン剤及びカーバメート骭の殺虫作用はコリンエ ステラーゼの阻害に起因するとされ，微小昆虫では桑原 (1984) がハダニで各系統の薬郕感受性と ChE の薬剤 感受性の問に高い相関が認められたと報告している。ミ ナミキイロアザミウマの場合にもそれとほぼ同様な関係 があるものと思われる。

摘

要

1. 無処理区, DMTP 水和剤及び BPMC 乳剤の淘汰
区を設け，両薬郕に対する感受性の推移を毎月 1 回，2

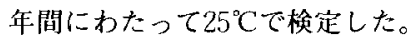

2. 無処理区では，DMTP 及び BPMC の感受性は2 〜 4 月頃が最も高く, 以後低下して 8 - 10月頃に最低と なったが，翌年の $2 \sim 4$ 月には前年と同程度の感受性に 復元した。

3. DMTP 及び BPMC の各御汰区でも, 無処理区と 同傾向の感受性の季節変動がみられた。両薬骫とも2 年 間23〜25回の淘汰で，年間に感受性が1/2に低下したが， 冬を越して $2 \sim 4$ 月には前年普の感受性に復元し，抵抗 性の発達は認められなかった。

4. DMTP 及び BPMC に対する感受性の程度と $\mathrm{ChE}$ の薬剤感受性の間には相関があるものと思われた。

\section{引用 文 献}

1) DitTRICH, V. (1963) Ent. exp. appl. 6:10-20. 2) 井上 晃一（1986）果樹試哌 E 6 : 117-180, 3) 風野 光・西野 敏勝（1986） 九病出研会報 $32: 166-168$, 4）桑原雅彦 (1984) 農技研報 C 39：1-75. 5) 松谷茂伸 (1967) 農薬 検筫所報告 $7: 41-45$, 6) 永田 徹・守谷茂雄（1974）応 動昆 18:73-80.

(1987年5月6日 受領) 